\section{Leonard Bernstein $\mathbf{y}$ "Casamiento de Negros"}

Leonard Bernstein and
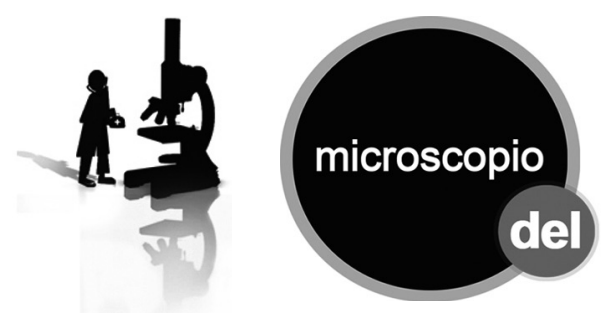

\title{
y la cultura
}

En 1971, el director y compositor estadounidense Leonard Bernstein (1918-1990) recibe el encargo de componer una pieza musical para la inauguración del "John F. Kennedy Center for the Performing Arts".

Bernstein, hijo de inmigrantes ucranianos, es considerado uno de los músicos norteamericanos más importantes del siglo veinte, y posiblemente uno de los más populares y queridos. Se hizo rápidamente conocido en 1943, a los 25 años, cuando tuvo que dirigir la Orquesta Filarmónica de Nueva York por enfermedad de su director titular, Bruno Walter.

Durante su vida se destacó por su participación en la vida política y social de su país, apoyando los derechos civiles, promoviendo la educación musical de la juventud y siendo un activo pacifista. Poco antes de morir dirigió la Novena Sinfonía de Beethoven en Berlín, para conmemorar la unificación y el fin de la guerra fría.

En 1951 se casó con la actriz chilena Felicia Cohn Montealegre, con quién tuvo tres hijos.

Cuando en 1971 recibió el encargo de Jacqueline Kennedy para la pieza inaugural del Kennedy Center, concibió una obra monumental, de marcado acento pacifista y humanista, a la vez que religioso, a la que denominó "Misa: Pieza teatral para cantantes, actores y bailarines". En ella emplea coro masculino y femenino, coro de niños, cantantes callejeros, actores, bailarines, orquesta sinfónica, banda de marchas y banda de rock.

Posiblemente influido por los gustos musicales de su esposa chilena, o tal vez por haber escuchado el arreglo de Baxter, Bernstein emplea nuevamente la melodía de "Casamiento de negros" esta vez en la epístola "La palabra de Dios", hermoso pasaje de la misa, estrenada en el Kennedy Center Opera House, el 8 de septiembre de 1971, cuatro años después de la trágica muerte de Violeta Parra.

Ernesto Payá $\boldsymbol{G}$.

Con la valiosa colaboración de Álvaro Gallegos M. Periodista de Radio Beethoven.

\section{Referencias}

1.- González J P, Ohlsen O, Rolle C. Violeta Parra. Historia Social de la Música Popular en Chile, 1950-1970. Ediciones Universidad Católica de Chile. Santiago. 2009.

2.- "Mass", en http://www.leonardbernstein.com/mass.htm 